\title{
IDENTIFIKASI TAHAP BERPIKIR GEOMETRI SISWA SMP NEGERI 2 AMBARAWA BERDASARKAN TEORI VAN HIELE
}

\author{
Susi Lestariyani \\ Alumni Program Studi Pendidikan Matematika \\ FKIP - Universitas Kristen Satya Wacana \\ Novisita Ratu \\ novisita.ratu@staff.uksw.edu \\ Program Studi Pendidikan Matematika \\ FKIP - Universitas Kristen Satya Wacana \\ Tri Nova Hasti Yunianta \\ 2., trinova.yunianta@staff.uksw.edu \\ Program Studi Pendidikan Matematika \\ FKIP - Universitas Kristen Satya Wacana
}

\begin{abstract}
ABSTRAK
Geometri dipelajari mulai dari sekolah dasar sampai di sekolah menengah atas. Beberapa kajian menunjukkan bahwa pada sekolah menengah pertama (SMP), banyak siswa memiliki kesulitan dalam belajar geometri. Level Geometri van Hiele dapat menjelaskan kesulitan geometri siswa. Van hiele menyatakan bahwa dalam memahami geometri, siswa perlu melalui lima level, diantaranya level 1 (tahap pengenalan), level 2 (tahap analisis), level 3 (tahap pengurutan), level 4 (tahap deduksi), dan level 5 (tahap ketepatan). Tujuan dari penelitian ini adalah untuk mendeskripsikan level berpikir geometri siswa sekolah menengah pertama. Ada 209 siswa yang masuk dalam penelitian ini. Metode penelitian yang digunakan adalah metode campuran. Intrumen tes yang digunakan diadaptasi dari Proyek CDASSG Usiskin. Hasilnya menunjukkan ada 28,71\% siswa SMP berada pada level 1, 44,02\% siswa berada pada level 2 dan 5,26 siswa berada pada level 3. Ada $1,91 \%$ siswa berada pada level 0 , dan tidak ada siswa yang berada pada level 4 dan 5 . Siswa Ada sekitar 20,10\% tidak dapat dikelompokkan ke dalam level yang ada dikarenakan tidak memenuhi kriteria dari instrumen penelitian. Berdasarkan hasil ini, siswa kebanyakan masih berada pada level 1 dan 2. Tidak seperti pendapat van Hiele yang menyatakan bahwa level berpikir geometri untuk siswa SMP berada di level 3. Berdasarkan hasil penelitian ini, penting untuk melakukan pemerikasaan lebih lanjut mengenai level berpikir geometri siswa SMP di tempat lain.
\end{abstract}

Kata Kunci : identifikasi, tahap berpikir geometri, teori van hiele 


\section{PENDAHULUAN}

Beberapa hasil penelitian menunjukkan bahwa siswa mengalami kesulitan dalam geometri (Budiarto, 2004). Kesulitan dan kesalahan konsep pada materi geometri tidak hanya dialami oleh siswa, tetapi juga oleh mahasiswa bahkan guru. Berdasarkan hasil penelitian Pradika dan Murwaningtyas (2012), dalam pembelajaran geometri siswa SMP menghafal rumus tetapi tidak mengetahui bagiamana penggunaannya dalam penyelesai-an soal. Hal ini dikarenakan siswa tidak memahami istilah dan simbol yang digunakan dalam soal geometri terutama jika disajikan dalam bentuk soal cerita. Hal ini meng-indikasikan bahwa siswa telah mempelajari konsep yang lebih tinggi tetapi belum matang pada hal-hal yang dasar.

Kesulitan siswa dalam geometri juga dialami oleh siswa SMP N 2 Ambarawa. Berdasarkan hasil wawancara, kemampuan siswa dalam memecahkan persoalan geometri lemah. Konsep-konsep bangun tidak tertanam kuat dalam diri siswa, sehingga siswa tidak memahami hubungan antar bangun seperti bahwa persegi merupakan bentuk khusus dari persegi panjang. Menurut Fathani (2009) dalam memperkenalkan simbol atau fakta matematika kepada siswa, guru seharusnya melalui beberapa tahap yang memungkinkan siswa dapat menyerap makna dari simbolsimbol tersebut.

Abdussakir (2010) menyatakan bahwa dalam pembelajaran geometri seharusnya memperhatikan tahap-tahap berpikir siswa. Hal ini sesuai dengan teori van Hiele, bahwa pembelajaran matematika khususnya geometri harus sesuai dengan tahap-tahap perkembangan kognitif siswa.

Van Hiele mengungkapkan bahwa dalam memahami geometri siswa melalui lima tahap. Setiap tahap menggambarkan proses berpikir siswa dalam konteks geometri. Tahap-tahap berpikir siswa dalam memahami geometri menurut van Hiele (Pitajeng, 2006) yakni tahap pengenalan, tahap analisis, tahap pengurutan, tahap deduksi, dan tahap ketepatan.

Salah satu karakterisitik dari teori van Hiele ialah adanya bahasa tersendiri pada setiap tahap. Dua individu (misal siswa dan guru) akan kesulitan berkomunikasi jika menggunakan pemikiran dan simbol linguistik yang berbeda dan menggunakan hubungan yang berbeda pula. Perbedaan tahap berpikir antara guru dan siswa dalam berkomunikasi dan tanpa memperhatikan tahap berpikir geometri siswa, hal tersebut diperkirakan menjadi kesulitan siswa dalam memahami konsep yang disampaikan oleh guru. Guru harus menyediakan pengalaman belajar yang cocok dengan tahap berpikir siswa, maka penting bagi guru untuk mengetahui tahap berpikir siswa dalam pembelajaran matematika khususnya materi geometri.

Siswa SMP diharapkan mencapai tahap 3 berpikir geometri. Hal ini karena berdasarkan beberapa penelitian jika siswa tidak mencapai tahap 3 berpikir geometri di SMP, maka siswa akan kesulitan dalam pembelajaran geometri di SMA (Usiskin, 1982; Senk, 1989). Berbeda dengan hasil penelitian Mustangin (2011) bahwa siswa sebagian besar siswa SMP beroperasi pada tahap 2 berpikir geometri van Hiele. Berdasarkan uraian di atas, maka perlu diadakan penelitian untuk mengetahui tingkat berpikir geometri siswa berdasarkan teori van Hiele. Oleh karena itu, peneliti melakukan penelitian dengan judul "Identifikasi Tahap Berpikir Geometri Siswa SMP Negeri 2 Ambarawa Berdasarkan Teori van Hiele" 


\section{KAJIAN PUSTAKA}

\section{Tahap Berpikir Geometri Van Hiele}

Teori van Hiel dikembangkan oleh dua orang pengajar Belanda pada tahun 1954. Teori ini berisi mengenai perkembangan kognitif geometri yang terdiri dari 5 tahap (Aisyah, 2007). Tiap tahapan menggambarkan proses berpikir yang diterapkan dalam konteks geometri. Terdapat dua cara penomoran yang berbeda dalam kajian yang mendiskripsikan tahap berpikir geometri siswa yakni tahap 0-4 dan tahap 1-5 (Senk, 1989). Awalnya van Hiele menggunakan tahap 0-4, tetapi pada kajian yang lebih baru menggunakan tahap 1-5 (Baffoe, 2010). Penelitian ini menggunakan cara penomoran tahap 1-5 sehingga memungkinkan untuk memberikan tahap 0 terhadap siswa yang berada di bawah tahap pengenalan berpikir van Hiele (Senk, 1989). Berikut deskripsi dari tiap-tiap tahap (Pitajeng, 2006; Aisyah, 2007; van de Walle, 2006):

Tahap pengenalan merupakan tahap pertama dalam tahap berpikir van hiele. Dalam tahap ini, siswa mulai belajar mengenal suatu bentuk geometri secara keseluruhan, tetapi belum mampu mengetahui adanya sifat-sifat keteraturan dari bentuk geometri yang dilihatnya itu. Siswa mengenal bentuk-bentuk berdasarkan pada karakteristik luar atau tampilan dari bentuk-bentuk tersebut. Tahap kedua dari tahap berpikir van Hiele ialah tahap analisis. Siswa pada tahap ini sudah mulai mengenal sifat-sifat/keteraturan yang dimiliki benda geometri yang diamati. Tahap pengurutan merupakan tahap 3. Tahap ini pemahaman siswa terhadap geometri lebih meningkat lagi dari sebelumnya yang hanya mengenal bangun-bangun geometri beserta sifat-sifatnya. Tahap deduksi merupakan tahap dimana siswa sudah mampu menarik kesimpulan secara deduktif, yakni berpikir berdasar-kan aturan-aturan yang berlaku dalam mate-matika Siswa telah memahami bahwa sistem lengkap dengan aksioma, definisi, teorema, efek dan postulat dapat dihargai sebagai alat dalam pembentukan kebenaran geometri. Tahap tertinggi dari tahap berpikir van Hiele yaitu tahap ketepatan. Siswa pada tahap telah memahami betapa pentingnya ketepatan prinsip-prinsip dasar yang melandasi suatu pembuktian. Ia mengetahui bahwa dengan dasar aksioma yang berbeda maka pernyataan benar untuk suatu hal yang sama akan berbeda pula.

\section{Karakteristik Berpikir Geometri van Hiele}

Teori yang diungkapkan oleh Pierre dan Dina van Hiele ini memiliki beberapa karakteristik (Aisyah, 2007). Karakteristik tersebut yakni: 1) belajar merupakan proses yang diskontinu; 2) tahapan-tahapan itu berurutan dan berhierarki serta kenaikan dari satu tahap ke tahap selanjutnya lebih banyak bergantung pada pembelajaran daripada umur atau kedewasaan biologis; 3) konsepkonsep yang secara implisit dipahami pada suatu tahap menjadi dipahami secara eksplisit pada tahap selanjutnya; 4) Setiap tingkat memiliki bahasanya sendiri, mempunyai simbol linguistiknya sendiri dan sisten relasinya sendiri yang menghubungkan simbolsimbol itu; 6) dua orang yang berada pada tingkat yang berbeda tidak dapat memahami satu sama lain.

Tiga unsur yang utama dalam pembelajaran geometri menurut Van Hiele (Aisyah, 2007) yakni waktu, materi pembelajaran dan metode pengajaran yang apabila dikelola secara terpadu akan dapat meningkatkan kemampuan berpikir siswa pada tahapan berpikir yang lebih tinggi. 
Secara khusus, van Hiele merancang suatu fase pembelajaran untuk meningkatkan tahap berpikir geometri siswa ke tahapan yang lebih tinggi. Terdapat lima fase pembelajaran van Hiele (Aisyah, 2007) yakni fase informasi, fase orientasi, fase eksplisitasi, fase orientasi bebas, dan fase integrasi.

\section{Geometri Bangun Datar SMP}

Geometri merupakan ilmu yang membahas tentang hubungan antara titik, garis, sudut, bidang dan bangun-bangun ruang. Euclid yang terkenal sebagai "Bapak Geometri" menyumbangkan sebagian besar konsep-konsep geometri yang digunakan sekarang. Geometri euclid inilah yang digunakan dalam kurikulum pembelajaran geometri di sekolah.

Salah satu bahasan yang sering ditemui siswa ialah bangun datar. Van Hiele dalam tulisannya juga mengunakan bangun datar untuk menjelaskan tahap berpikir geometrinya. Pada tingkat SMP materi bangun datar, terutama segitiga dan segimpat dipelajari siswa mulai kelas VII.

\section{Penelitian Yang Relevan}

Identifikasi tahap berpikir siswa SMP telah banyak dilakukan. Penelitian Mustangin (2011) menunjukkan bahwa siswa SMP di kota Malang sebagian besar berada pada tahap 2 (analisis). Penelitian ini dilakukan terhadap 165 siswa di kota Malang. Sebanyak $33,9 \%$ siswa berada pada tahap 3 . Hasil yang berbeda diberikan oleh Syafi'i (2011) di mana keenam subjek siswa SMP dalam menyelesaikan soal bangun ruang hanya mencapai tahap 1 tahap berpikir gometri van Hiele.

Berbeda pula dengan hasil penelitian Nurhasanah (2004) di mana dari ketiga subjek SMP kelas VIII yang diteliti diperoleh hasil yang berbeda-beda. Satu siswa berada pada antara tahap 1 dan 2 , satu siswa berada di antara tahap 2 dan 3, sedangkan siswa lainnya berada di antara tahap 3 dan 4 .

\section{METODE PENELITIAN}

Penelitian ini merupakan penelitian kuantitatif deskriptif. Penelitian ini mendiskripsikan tahap berpikir geometri siswa SMP berdasarkan teori Van Hiele. Penelitian ini dilakukan di SMP Negeri 2 Ambarawa yang dilaksanakan pada bulan Maret 2013.

Populasi dalam penelitian ini merupakan siswa SMP N 2 Ambarawa. Sampel berjumlah 209 siswa yang berasal dari 8 kelas VII dan kelas VIII. Sampel diambil menggunakan proportionate stratified random sampling yakni memilih sampling berdasarkan stratifikasi yang dalam penelitian ini stratifikasi kelas VII dan VIII. Kelas IX tidak memungkinkan untuk menjadi sampel karena adanya kebijaksanaan sekolah, sehingga kelas IX termasuk sampel yang berada di luar jangkauan. Penelitian ini menggunakan metode tes. Pemberian tes dilakukan di ruang kelas masing-masing subjek. Waktu pengerjaan tes yakni 1 jam pelajaran atau 40 menit.

Instrumen yang digunakan pada penelitian ini mengadopsi Van Hiele Geometry Test (VHGT) yang dikembangkan oleh Usiskin (1982) pada CDASSG Project yang diterjemahkan ke dalam bahasa Indonesia. Instrumen berupa soal pilihan ganda sebanyak 25 butir yang dibagi dalam 5 subtes. Masingmasing subtes mewakili satu tahap van Hiele.

Setiap subtes terdiri dari lima butir soal pilihan ganda dengan 5 pilihan jawaban. Data hasil tes diubah dalam bahasa numerik. Setiap nomor benar diberi skor 1 dan jika salah diberi skor 0 . Siswa dianggap telah lulus suatu tahap jika memenuhi kriteria yakni minimal mengerjakan benar 3 dari 5 butir 
soal tiap subtesnya. Lulusnya tahap 2, 3 ,4 dan 5 dapat dilalui jika sudah lulus pada tahap sebelumnya. Jika siswa mencapai tahap n tetapi tidak memenuhi semua tahap di bawahnya akan dikategorikan sebagai "nofit". Tahap 0 diberikan kepada siswa yang tidak memenuhi kriteria menjawab benar 3 dari 5 butir soal pada semua subtes.

\section{HASIL}

Penelitian ini dilaksanakan di SMP Negeri 2 Ambarawa. Subjek yang digunakan dalam penelitian ini berjumlah 209 siswa yang terdiri dari kelas VII dan kelas VIII.Penelitian ini dilaksanakan dari bulan Januari sampai Mei 2013.

\section{Hasil Siswa pada Van Hiele Geometry Test (VHGT)}

Jawaban siswa dikelompokkan pada masing-masing butir Van Hiele Geometry Test (VHGT. Terdapat lima subtes di mana masing-masing subtes mewakili satu tahap berpikir geometri van Hiele.

Sebagian besar siswa mampu menjawab soal dengan benar pada subtes 1 , terutama pada keempat butir soal pertama. Sebesar 89,95\% siswa lulus pada tahap 1 ini dengan kriteria menjawab benar 3 dari 5 butir soal. Hasil siswa pada subtes 2 cukup baik yakni lebih dari $60 \%$ siswa memenuhi kriteria menjawab benar 3 dari 5 butir soal, sedangkan pada subtes 3 tidak cukup baik. Hanya 8,61\% siswa yang mampu memenuhi kriteria menjawab benar 3 dari 5 butir soal pada subtes ini.

Sama seperti subtes 3, hasil siswa pada VHGT subtes 4 tidak cukup baik. Hanya $5,26 \%$ siswa memenuhi kriteria pada subtes ini. Respon siswa terhadap subtes 5 secara keseluruhan tidak cukup baik. Hanya 8,61\% siswa yang memenuhi kriteria pada subtes ini. Menarik bahwa persentase ini lebih tinggi daripada subtes 4 yang hanya 5,26\%. Perlu diperhatikan subtes 5 ini digunakan untuk mengidentifikasi tahap 5 berpikir geometri van Hiele, sehingga tingkat kesulitan subtes 5 lebih tinggi dibandingkan dengan subtes 4 .

\section{Tahap Berpikir Geometri Siswa SMP}

Penentuan tahap berpikir geometri siswa tidak hanya berdasarkan pada subtes yang berhasil dipenuhi kriterianya. Merupakan salah satu karakteristik berpikir geometri van Hiele, bahwa setiap tahap harus dilalui secara urut, tidak melompati tahap di bawahnya. Siswa yang tidak memenuhi satupun kriteria menjawab benar 3 dari 5 dari semua subtes maka dikategorikan sebagai tahap 0. Tahap 0 ini menunjukkan bahwa siswa belum sampai pada tahap berpikir van Hiele. Tahap 0 ini bukan merupakan bagian dari teori van Hiele. Tahap 0 ini digunakan untuk menunjuk pada siswa yang tidak memenuhi satupun dari lima subtes pada tes.

Siswa yang tidak memenuhi satupun dari kelima subtes VHGT sebesar 1,91\% siswa. Persentase ini menunjukkan bahwa sebagian besar siswa SMP telah memasuki tahap berpikir geometri van Hiele. Sebesar $28,71 \%$ siswa berada pada tahap 1 . Sebagian

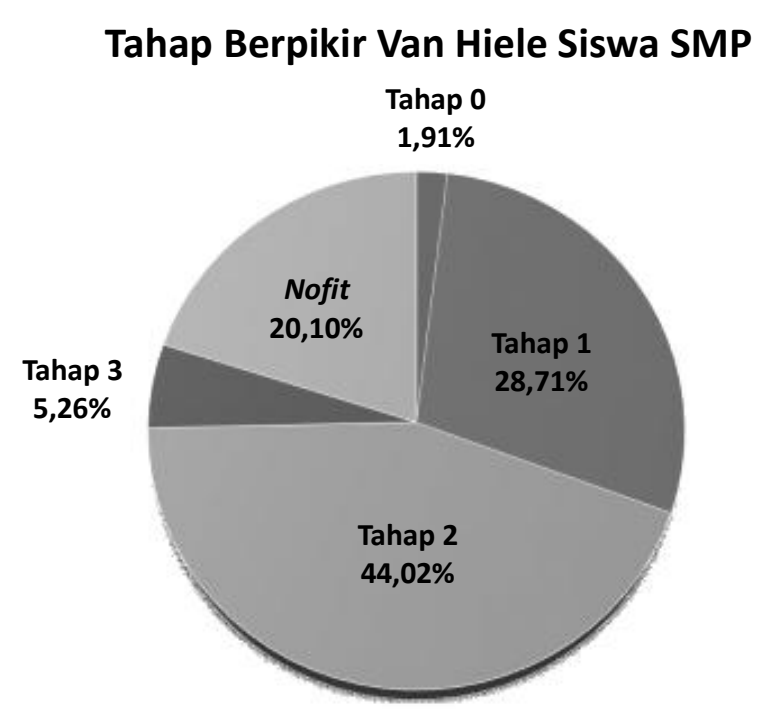


besar siswa SMP N 2 Ambarawa berada pada tahap 2 berpikir geometri van Hiele yaki dengan persentase $44,02 \%$ siswa. Tahap ketiga berpikir geometri van Hiele merupakan tahap pengurutan. Siswa SMP diharapkan berada pada tahap ini. Hanya $5,26 \%$ siswa siswa yang berada pada tahap ini. Tidak ada siswa yang berada pada tahap 4 dan 5.

Siswa yang tidak dapat dikategorikan dalam tahap van Hiele terdapat 20,10\% dari 209 siswa. Terdapat dua belas tipe jawaban siswa yang tidak dapat dikategorikan dalam tahap berpikir geometri van Hiele. Sebanyak $26,19 \%$ dari 42 siswa hanya memenuhi kriteria pada subtes 2 saja, sedangkan pada subtes 1 tidak. Siswa-siswa ini tidak dapat dikategorikan sebagai tahap 2 karena melompati tahap 1 walaupun telah memenuhi kriteria menjawab benar 3 dari 5 butir soal pada subtes 2 .

Siswa kelas VII dengan persentase yang hampir sama berada pada tahap 1 dan 2 yakni $34,65 \%$ dan $35,64 \%$, sedangkan siswa kelas VIII sebagian besar berada pada tahap 2 yakni 51,85\% siswa. Persentase ini diikuti oleh siswa yang berada pada tahap 1 yakni $23,15 \%$ siswa. Hal yang menarik bahwa dari 11 siswa yang berada pada tahap 3, 8 diantaranya merupakan siswa kelas VII. Secara keseluruhan, siswa kelas VIII berada pada tahap berpikir van Hiele sedikit lebih tinggi dibandingkan kelas VII.

Tahap berpikir van Hiele antara siswa perempuan dan laki-laki hampir sama. Siswa laki-laki sebagian besar berada pada tahap 2 begitu pula dengan siswa perempuan dengan persentase yang terpaut kecil yakni hanya $4,53 \%$ lebih banyak laki-laki. Pada tahap 1, siswa perempuan menempati persentase yang lebih banyak yakni sebesar 5,45\% dibandingkan laki-laki. Hal ini menunjukkan bahwa tidak ada perbedaan antara siswa laki-laki dan perempuan dalam tahap berpikir geometri van Hiele.

\section{PEMBAHASAN}

Secara keseluruhan siswa SMP Negeri 2 Ambarawa berada pada tahap 1 dan 2 berpikir geometri van Hiele. Sebagian besar siswa berada pada tahap 2 yakni dengan persentase $44,02 \%$, kemudian diikuti siswa yang berada pada tahap 1 yakni dengan persentase $28,71 \%$. Hanya 5,26\% siswa yang berada pada tahap 3. Masih terdapat siswa yang berada pada tahap 0 . Tidak ada siswa telah berada pada tahap 4 dan 5 van Hiele.

Merupakan suatu kelemahan menggunakan metode tes bahwa terdapat siswa yang tidak dapat ditentukan tahap berpikirnya karena melompati tahap-tahap tertentu. Sebesar 79,90\% siswa dapat ditentukan tahap berpikir van Hiele-nya, sedangkan 20,10\% tidak dapat ditentukan tahap ber-pikirnya dengan menggunakan instrumen ini.

Hasil dari penelitian ini menunjukkan bahwa secara umum siswa SMP N 2 Ambarawa berada pada tahap 1 dan 2, hal ini belum sesuai dengan pendapat van de Wall (2006) bahwa siswa SMP diharapkan berada pada tahap 3 berpikir van Hiele. Siswa akan mengalami kesulitan pada pembelajaran geometri di SMA jika minimal tidak berada pada tahap 3 sebelum memasuki SMA.

Van Hiele menyatakan bahwa pengalaman geometri yang terjadi merupakan faktor utama yang menentukan tahap berpikir siswa. Siswa seharusnya membangun konsep-konsep geometri ini secara wajar tanpa dipaksakan atau diberikan secara instan dari luar. Fasilitas dan dukungan guru diperlukan, terutama untuk mem- 
beri bimbingan mengenai pengharapan dalam pembelajaran.

Berdasarkan hal tersebut, maka perlu menjadi perhatian bagi guru untuk memberikan pengalaman belajar geometri yang sesuai dengan tahap berpikir siswa. Siswa SMP yang berada pada tahap 2, akan mengalami kesulitan jika diberikan pembelajaran dengan tahap 3 dan seterusnya. Hal ini dikarenakan setiap tahap van Hiele memiliki bahasanya sendiri, sehingga dua individu yang berada pada tahap yang berbeda akan tidak saling mengerti dan yang satu akan kesulitan mengikuti yang lain. Siswa yang harus berpikir pada objek-objek pada tahapan di atasnya, mungkin terpaksa belajar di luar kepala dan hanya bersifat sementara dan dangkal.

Melihat hasil penelitian bahwa siswa berada pada tahap 1 dan 2 juga perlu menjadi perhatian. Selain perlunya pembelajaran yang sesuai dengan tahap berpikir siswa, maka pembelajaran yang terjadi seharusnya juga dapat meningkatkan tahap berpikir siswa ke tahap selanjutnya. Hal ini diperlukan, karena sebelum memasuki SMA minimal siswa telah berada pada tahap 3 agar bisa mengikuti pembelajaran geometri di SMA dengan baik. Pembelajaran yang memberikan kesempatan siswa menelusuri, berdiskusi dan berinteraksi dengan materi pada tahapan selanjutnya sambil meningkatkan pengalaman mereka pada tahap saat ini memiliki kesempatan terbaik dalam mengembangkan tahap pemikiran bagi siswa (van de Walle, 2006).

Sesuai dengan Frykholm (1994), bahwa jenis kelamin tidak memiliki andil dalam menentukan tahap berpikir siswa. Hal ini terlihat dari persentase jumlah siswa lakilaki dan perempuan pada tahap berpikir geometri van Hiele cenderung sama.
Secara umum, hasil penelitian ini menunjukkan bahwa siswa SMP berada pada tahap 1 dan 2 berpikir van Hiele. Hasil ini belum sesuai dengan harapan bahwa siswa SMP seharusnya berada pada tahap 3. Satu hal yang menjadi faktor utama terhadap hasil ini yakni pengalaman pembelajaran geometri siswa. Diperlukan penelitian lebih lanjut untuk mengetahui tentang pembelajaran geometri yang terjadi di sekolah kemudian menentukan metode yang tepat untuk meningkatkan tahap berpikir geometri siswa.

\section{PENUTUP}

Secara keseluruhan siswa SMP berada pada tahap 1 dan 2 berpikir geometri berdasarkan teori van Hiele. Tidak ada perbedaan tahap berpikir van Hiele pada siswa laki-laki dan perempuan pada tingkat SMP. Guru perlu merancang pembelajaran matematika khususnya geometri dengan memperhatikan tahap berpikir geometri siswa. Metode yang digunakan juga kiranya dapat meningkatkan tahap berpikir siswa SMP yang masih pada tahap 1 dan 2 menuju tahap berpikir ideal yaitu tahap 3 . Peneliti selanjutnya perlu mengkaji lebih jauh mengenai faktor-faktor penyebab siswa SMP masih berada pada tahap 1 dan 2 tahap berpikir geometri, mengingat tahap ideal siswa SMP pada tahap 3. Kemudian menemukan metode pembelajaran yang tepat untuk meningkatkan tahap berpikir geometri siswa.

\section{DAFTAR PUSTAKA}

Abdussakir. 2010. Pembelajaran Geometri Sesuai Teori Van Hiele, El Hikmah: Jurnal Kependidikan dan Keagamaan, Vol. VII, No. 2, Januari 2010, ISSN 1693 - 1499. Fakultas Tarbiyah UIN Maliki Malang. 
Aisyah, N., dkk. 2007. Pengembangan Pembelajaran Matematika SD. Jakarta: Deriktorat Jenderal Pendidikan Tinggi Departemen Pendidikan Nasional.

Baffoe, E. 2010. The van Hiele Levels of Understanding of Students entering Senior High School in Ghana. Skripsi: University of Education, Winneba. Tidak diterbitkan.

Budiarto, M. T. 2004. Karakteristik Tentang Bentuk Kesalahan Dalam Menyelesaikan Permasalahan Geometri. Disajikan dalam Seminar Nasional IMSTEP JICA, FMIPA-UNY, 2004.

Fathani, A. H., dkk. 2009. Matematika: Hakikat dan Logika. Yogyakarta: ArRuzz Media.

Mustangin. 2011. Profil Pencapaian Tahap berpikir Siswa SMP di Kota Malang Dalam Belajar Geometri Berdasarkan Tahap Berpikir Van Hiele. Jurnal Pendidikan Matematika FKIP Universitas Muhammadiyah, vol. 2, no. 2.

Nurhasanah, F. 2004. Proses Berpikir Siswa Sekolah Menengah Tingkat Pertama Dalam Belajar Geometri pada Pokok Bahasan Jajargenjang, Belah Ketupat, Layang-layang dan Trapesium Tahun Pelajaran 2003/2004. Skripsi: Universitas Sebelas Maret Surakarta.
Pitajeng. 2006. Pembelajaran Matematika yang Menyenangkan. Jakarta: Departemen Pendidikan Nasional Direktorat Jenderal Pendidikan Tinggi Direktorat Ketenagakerjaan.

Pradika, L. E. dan Murwaningtyas, E. 2012. Analisis Kesalahan Siswa kelas VIII SMPN 1 Karanganyar Dalam Mengerjakan Soal pada Pokok Bahasan Bangun Ruang Sisi Datar Serta Upaya Remediasinya dengan Media Bantu Program Cabri 3D. Seminar Nasional Matematika dan Pendidikan Matematika, UNY 2012.

Senk, S. L. 1989. Van Hiele Levels and Achievment in Writing Geometry Proofs, Journal for Research in Mathematic Education, vol. 20, no. 3: pp. 309-321.

Syafi'i, A. 2011. Identfikasi Tingkat berpikir Siswa Berdasarkan Teori Van Hiele dalam Menyelesaikan Masalah Geometri Bangun Ruang Sisi Datar Siswa SMP N 3 Taman Sidoarjo. Skripsi tidak diterbitkan.

Usiskin, Z. 1982. Van Hiele Levels and Achievment In Secondary School Geometry. CDASSG Project.

Van De Walle, A. J. 2006. Matematika Sekolah Dasar dan Menengah Jilid 2. Bandung: Erlangga. 